\title{
Spontaneouse Pneumomediastinum with Subcutaneous Emphysema in an Adolescent Boy
}

\section{Subkutan Amfizem ile Gelen Spontan Pnömomediastinumlu Bir Erkek Adölesan}

\author{
Filiz Serdaroğlu1, Tuğba Koca1, Isa Döngel2, Mustafa Akçam1 \\ ${ }^{1}$ Süleyman Demirel University Faculty of Medicine, Department of Pediatrics, Division of Pediatric Gastroenterology, Hepatology and Nutrition, \\ Isparta, Turkey \\ 2Süleyman Demirel University Faculty of Medicine, Department of Thoracic Surgery, Isparta, Turkey
}

\begin{abstract}
Spontaneous pneumomediastinum, which generally develops as a result of alveoli bursting under pressure, is rarely seen in children and may cause families and physicians to panic. Acute or chronic pulmonary disease is expected in the etiology. However, it may also be seen with exercises which increase pulmonary pressure, without any facilitating factor. The case presented here is of an adolescent with no known pulmonary disease, who presented with chest pain that had started during the normal activity of a game and the diagnosis of spontaneous pneumomediastinum was missed in the first physical examination.

Keywords: Children, spontaneous pneumomediastinum, subcutaneous emphysema
\end{abstract}

ÖZ

Spontan pnömomediastinum genellikle basınçtan dolayı alveollerin patlaması sonucu gelişen, çocuklarda nadir görülen, aile ve hekimi paniğe sevk edebilen bir hastalıktır. Etiyolojide akut veya kronik akciğer hastalığııın olması beklenen bir durumdur. Ancak hiçbir kolaylaştırııı faktör olmadan da akciğer basıncını arttırııı egzersizler ile görülebilmektedir. Burada, bilinen hiçbir akciğer hastalığı olmayan bir adölesanda normal aktiviteli oyun sırasında göğüs ağrısı ile başlayan ve ilk muayene ile tanısı atlanan spontan pnömomediastinum olgusunu sunup literatür ışı̆̆ı altında tartışmak istedik.

Anahtar Kelimeler: Çocuk, spontan pnömomediastinum, derialtı amfizem

\section{Introduction}

Isolated pneumomediastinum is a rarely seen event in children. Although chronic pulmonary diseases play a role in the etiology, primarily asthma, it can also be seen associated with illicit drug use, rapid ascent scuba diving, foreign body ingestion and blast injury. In some children, however, it may develop without any risk factor $(1,2)$. Generally, it becomes evident with sudden onset chest pain and respiratory problems (3). Diagnosis can be made with the support of anterior-posterior
(AP) pulmonary radiographs and computed tomography (CT). In this paper, it was aimed to discuss in the light of the relevant literature, the case of an adolescent who developed chest pain while playing and the diagnosis of pneumomediastinum was missed from the first examinations and tests.

\section{Case Report}

A 15-year old male experienced sudden onset chest pain while running during a game, and distress while breathing,

\footnotetext{
Address for Correspondence/Yazıșma Adresi

Filiz Serdaroğlu MD, Süleyman Demirel University Faculty of Medicine, Department of Pediatrics, Division of Pediatric Gastroenterology, Hepatology and Nutrition, Isparta, Turkey 
tightness, throat swelling, painful swallowing and a change in voice, so presented at an external healthcare centre where he was evaluated in respect of cardiology and ear, nose and throat. As the pulmonary radiograph and echocardiography results were normal, he was discharged. After 12 hours he presented again as the complaints had not improved, was determined as tachycardic and was transferred to our hospital.

The physical examination results were body weight 91 $\mathrm{kg}$ (>97 p), height $190 \mathrm{~cm}$ (>97 p), arterial blood pressure: 120/70 $\mathrm{mmHg}$, respiratory rate: 24/min, heart rate: 76/ min. The general condition of the patient was good with full consciousness. Crepitation (+) was determined in the left side of the neck, in the left side of the chest and in the left axillary region. The other system examination findings were normal. The laboratory test results were hemoglobin: $14.2 \mathrm{~g} / \mathrm{dL}$, white blood cell: $12.000 / \mathrm{mm}^{3}$, platelet: $225.000 /$ $\mathrm{mm}^{3}$, glucose: $91 \mathrm{mg} / \mathrm{dL}$, blood urea nitrogen: $13 \mathrm{mg} /$ $\mathrm{dL}$, creatine: $0.9 \mathrm{mg} / \mathrm{dL}$, uric acid: $6 \mathrm{mg} / \mathrm{dL}$, aspartate aminotransferase: $35 \mathrm{IU} / \mathrm{L}$, alanine aminotransferase: 32 IU/L, gamma-glutamyltransferase: $14 \mathrm{IU} / \mathrm{L}$, albumin: $4.9 \mathrm{~g} /$ $\mathrm{dL}$, creatine kinase: $183 \mathrm{mg} / \mathrm{dL}$, creatine kinase-MB: $31 \mathrm{mg}$, C-reactive protein: $3.4 \mathrm{mg} / \mathrm{dL}$, erythrocyte sedimentation rate: $10 \mathrm{~mm} / \mathrm{h}$. Electrolytes were normal, peripheral oxygen saturation was 97\%, blood gases were $\mathrm{pH}$ : 7.39, partial pressure of carbon dioxide: 35.5 , base excess: $-3.1, \mathrm{HCO}_{3}$ : 21.9 and echocardiography was normal.

On the AP chest radiograph, there was an appearance consistent with subcutaneous emphysema in the neck and air in the mediastinum (Figure 1). On the thorax CT, in addition to the pneumomediastinum, the image was consistent with evident subcutaneous emphysema especially in the

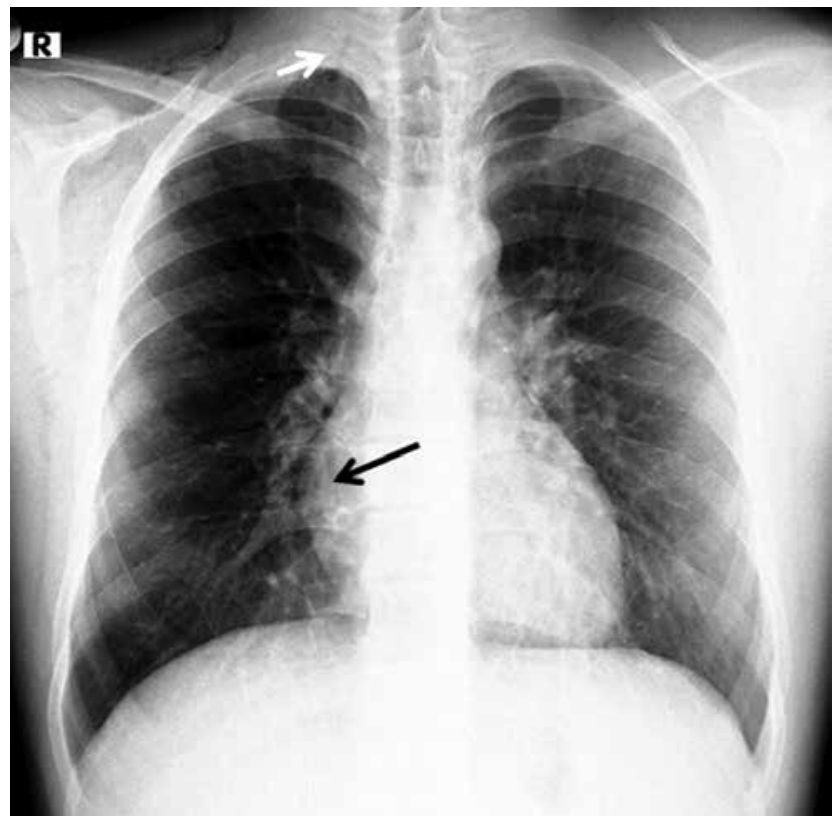

Figure 1. Frontal chest radiography showing pneumomediastinum (black arrow) and associated subcutaneous emphysema (white arrow) neck (Figure 2a, b). The patient was admitted to the clinic with a diagnosis of spontaneous pneumomediastinum. Intermittent $\mathrm{O}_{2} 2 \mathrm{~L} / \mathrm{min}$ was administered nasally. Oral intake was stopped. Upper gastrointestinal endoscopy was applied in respect of esophagus rupture, but as no pathology was encountered, oral intake was recommenced. Monitoring was applied with daily AP chest radiographs. In the clinical and radiological follow-up, as there were no findings suggesting tracheal rupture, bronchoscopy was not applied. On the $4^{\text {th }}$ day, as the general condition of the patient had improved and was stable, blood gas values were seen to be normal, the subcutaneous emphysema had reduced and improvement was seen radiologically, the patient was discharged. At follow-up examinations in the clinic, the patient had no complaints and the physical examination was normal.

\section{Discussion}

Spontaneous pneumomediastinum is an uncommon and primarily benign entity that probably arises from alveolar rupture after an acute rise in intrathoracic pressure, which may develop in many patients without a history of an obvious precipitating event (1). Although chronic pulmonary diseases such as asthma are often seen as precipitating events, it may also be seen following intense sporting activities, deep water diving, foreign body ingestion, blunt trauma, tooth extraction, drug inhalation and acute pulmonary infections (1,3-9).

In the current case, there was no precipitating factor except cigarette smoking. The chest pain started suddenly during a sporting activity that did not require particular exertion. At the hospital where the patient first presented, evaluation was made in respect of cardiology and ear, nose and throat and diagnosis was not made. As the complaints did not improve, when the patient presented at our hospital, evaluation was made with Posterior to Anterior chest radiograph and thoracic CT and a diagnosis was made of pneumomediastinum and subcutaneous emphysema. If it is considered that generally it is not necessary to make many tests and interventional procedures in healthy children for diagnosis and treatment of this illness which is benign and
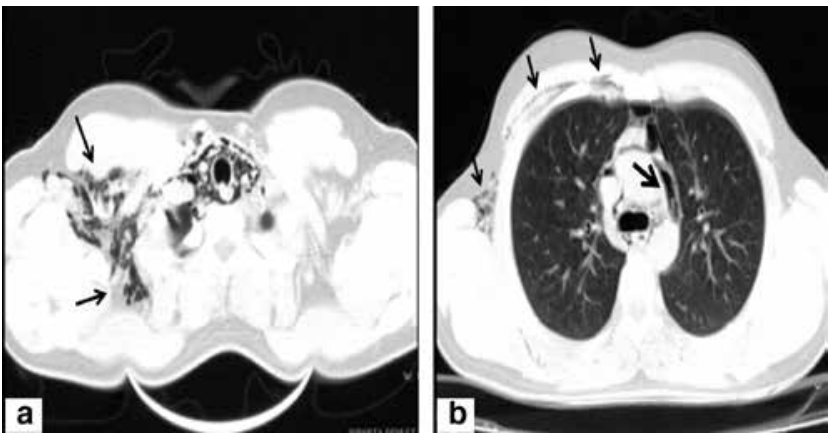

Figure 2. a) Computed thorax tomography showing air in soft tissue of neck (black arrow), b) Computed thorax tomography with lung windows demonstrate subcutaneous emphysema (thin arrow) and pneumomediastinum (thick arrow) 
self-limiting, CT, oesophagoscopy, bronchoscopy and barium swallows are often recommended in the treatment algorithm $(1,2)$.

In the current case, diagnosis was made with $\mathrm{CT}$ and upper gastrointestinal endoscopy was applied to be sure that the oesophagus was normal and to be able to start oral nutrition. In the clinical and radiological follow-up, as there were no findings suggesting tracheal rupture, bronchoscopy was not applied.

Patients with spontaneous pneumomediastinum usually complain of some chest discomfort, often radiating to the neck or back, and shortness of breath, at times accompanied by hoarseness or coughing. Most look completely well with normal vital signs $(1,2)$. In the current case, there was chest pain, pain in the neck, respiratory problems and vocal changes. Vital signs were all normal.

The history can be key. Weightlifting and other sportsrelated activities are known to be the instigating factor in many patients $(1,3)$. In the current case, the patient became unwell during a sporting activity although it was not intense.

The valsalva maneuver, which increases alveolar pressure and results in rupture, was presumed to be the cause of the current case. In addition to the risk factors such as chronic or acute pulmonary disease, drug abuse with the inhalation of substances should be carefully questioned. In the current case, there were no risk factors apart from cigarette smoking.

In consideration of the benign natural history of spontaneous pneumomediastinum in a child who otherwise appears well with no progression of symptoms, the recommended treatment is a short period of emergency room observation, no further imaging studies, and ultimate discharge home for relative rest with avoidance of lifting or valsalva $(1,2)$.

In the current case, the patient was monitored in the clinic for 3 days with a symptomatic approach. In the clinical and radiological follow-up, as the general condition progressed well, the patient was discharged from the polyclinic without the application of any advanced intervention or treatment.

In conclusion, it should be kept in mind that spontaneous pneumomediastinum could develop without excessive exertion or any risk factor in adolescents. Therefore, in suspicious cases with vocal changes, diagnosis must be confirmed with thoracic CT and there must be awareness of possible esophagus and tracheal rupture.

\section{Ethics}

Informed Consent: Was optained from patient and his parent.

Peer-review: External and Internal peer-reviewed.

\section{Authorship Contributions}

Surgical and Medical Practices: Isa Döngel, Mustafa Akçam, Concept: Filiz Serdaroğlu, Tuğba Koca, Design: Tuğba Koca, Data Collection or Processing: Filiz Serdaroğlu, Analysis or Interpretation: Mustafa Akçam, Literature Search: Filiz Serdaroğlu, Tuğba Koca, Writing: Filiz Serdaroğlu, Mustafa Akçam.

Conflict of Interest: No conflict of interest was declared by the authors.

Financial Disclosure: The authors declared that this study has received no financial support.

\section{References}

1. Fitzwater JW, Silva NN, Knight CG et al. Management of spontaneous pneumomediastinum in children. J Pediatr Surg 2015;50:983-6.

2. Bakhos CT, Pupovac SS, Ata A, Fantauzzi JP, Fabian T. Spontaneous pneumomediastinum: an extensive workup is not required. J Am Coll Surg 2014;219:713-7.

3. Tsai HH, Lo YH, Chiu WY. Adolescent spontaneous pneumopericardium after playing table tennis. OJM 2014;107:941-2.

4. Laitila M, Eskola V. Spontaneous pneumomediastinum in an 11-year-old boy after a shallow breath-hold dive. Diving Hyperb Med 2013;43:235-6.

5. Padhy AK, Gupta A, Aiyer P, et al. Spontaneous pneumomediastinum: A complication of swine flu. Asian Cardiovasc Thorac Ann 2015;23:1000

6. Reed JA, Larson KE, Hsu BS. Spontaneous pneumomediastinum with subcutaneous emphysema: report of two pediatric cases. S D Med 2013;66:89,91-3.

7. Wong KS, Wu HM, Lai SH, Chiu CY. Spontaneous pneumomediastinum: analysis of 87 pediatric patients. Pediatr Emerg Care 2013;29:988-91.

8. Maithani T, Dey D, Sharma C. Spontaneous cervicofacial subcutaneous emphysema secondary to pneumomediastinum in an otherwise asymptomatic child. Ear Nose Throat J 2012;91:E9-E11.

9. Döngel I, Bayram M, Uysal IO, Sunam GS. Subcutaneous emphysema and pneumomediastinum complicating a dental procedure. Ulus Travma Acil Cerrahi Derg 2012;18:361-3. 